\title{
Copper tolerance mediated by polyphosphate degradation and low-affinity inorganic phosphate transport system in Escherichia coli
}

\author{
Mariana Grillo-Puertas', Lici Ariane Schurig-Briccio ${ }^{1,2}$, Luisa Rodríguez-Montelongo ${ }^{1}$, María Regina Rintoul ${ }^{1}$ \\ and Viviana Andrea Rapisarda ${ }^{* *}$
}

\begin{abstract}
Background: Metal tolerance in bacteria has been related to polyP in a model in which heavy metals stimulate the polymer hydrolysis, forming metal-phosphate complexes that are exported. As previously described in our laboratory, Escherichia coli cells grown in media containing a phosphate concentration $>37 \mathrm{mM}$ maintained an unusually high polyphosphate (polyP) level in stationary phase. The aim of the present work was to evaluate the influence of polyP levels as the involvement of low-affinity inorganic phosphate transport (Pit) system in E. coli copper tolerance.

Results: PolyP levels were modulated by the media phosphate concentration and/or using mutants in polyP metabolism. Stationary phase wild-type cells grown in high phosphate medium were significantly more tolerant to copper than those grown in sufficient phosphate medium. Copper addition to tolerant cells induced polyP degradation by PPX (an exopolyphosphatase), phosphate efflux and membrane polarization. $p^{-} k^{-} p p x^{-}$(unable to synthesize/degrade polyP), $p p x^{-}$(unable to degrade polyP) and Pit system mutants were highly sensitive to metal even in high phosphate media. In exponential phase, CopA and polyP-Pit system would act simultaneously to detoxify the metal or one could be sufficient to safeguard the absence of the other.

Conclusions: Our results support a mechanism for copper detoxification in exponential and stationary phases of E. coli, involving Pit system and degradation of polyP. Data reflect the importance of the environmental phosphate concentration in the regulation of the microbial physiological state.
\end{abstract}

Keywords: Escherichia coli, Copper tolerance, Stationary phase, Polyphosphate, Inorganic phosphate

\section{Background}

Inorganic polyphosphate (polyP) is a linear polymer of hundreds of orthophosphate residues linked by phosphoanhydride bonds. The main enzymes associated with polyP metabolism in bacteria are polyphosphate kinase (PPK, encoded by $p p k$ ) and exopolyphosphatase (PPX, encoded by $p p x)[1,2]$. In most organisms, including bacteria, archaea and eukaryotes, metal tolerance was related to polyP levels [3]. Rachlin et al. [4] have proposed that polyP, as a metal chelator, reduces intracellular heavy metals concentration in the Cyanophycean alga Plectonema boryanum. Similarly, resistance to cadmium

\footnotetext{
* Correspondence: vrapisarda@fbgf.unt.edu.ar

'Instituto Superior de Investigaciones Biológicas, INSIBIO (CONICET-UNT) and Instituto de Química Biológica "Dr Bernabé Bloj", Facultad de Bioquímica, Química y Farmacia (UNT), Chacabuco 461 CP T4000ILI, Tucumán, Argentina Full list of author information is available at the end of the article
}

in Anacystis nidulans R2 strain [5] and in Klebsiella aerogenes [6] was related to high polyP levels. Keasling proposed a model where metals $\left(\mathrm{Na}^{+}, \mathrm{Mg}^{2+}, \mathrm{Co}^{2+} \mathrm{Cd}^{2+}\right)$ can be chelated by polyP and/or regulate the activity of PPX, which would in turn degrade polyP, allowing the removal of metal-phosphate complexes possibly via lowaffinity inorganic phosphate transport (Pit) system [7]. This model was supported in acidophilic bacteria [8] and archaea [9], where $\mathrm{Cu}^{2+}$ increases PPX activity and phosphate (Pi) efflux.

Pit system in Escherichia coli includes PitA (encoded by pitA) and PitB (encoded by pitB) [10]. van Veen et al. [11] have shown that Pit can reversibly transport $\mathrm{Ca}^{2+}$, $\mathrm{Co}^{2+}$ or $\mathrm{Mg}^{2+}$ phosphates in E. coli and Acinetobacter johnsonii. The uptake of a neutral metal-phosphate (MeHPO) complex is mediated by an electrogenic 


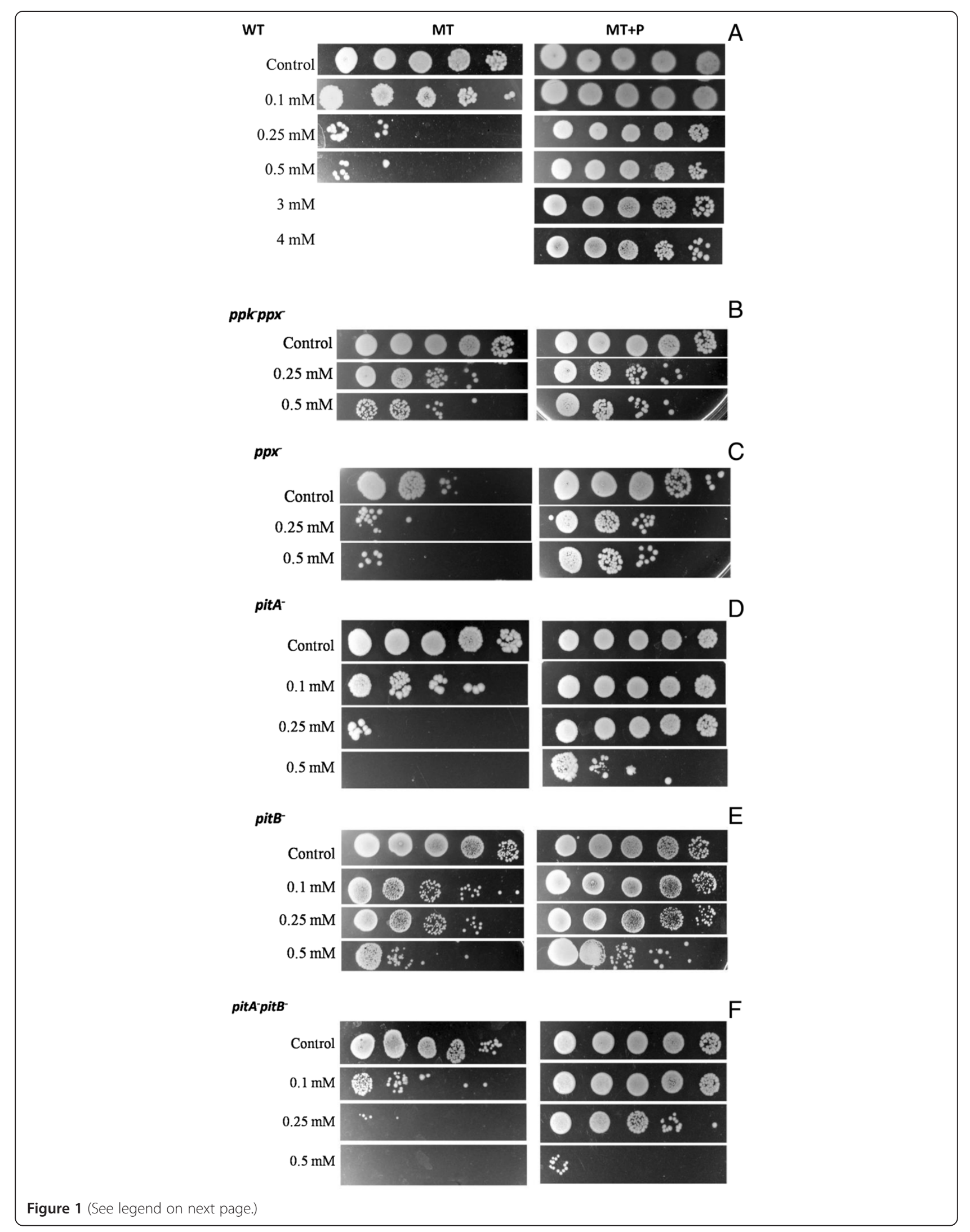


(See figure on previous page.)

Figure 1 Copper tolerance in stationary phase cells. Copper tolerance of $48 \mathrm{~h} \mathrm{MT}$ or MT + P growing cells of the indicated strains (panels A-F) was determined after one-hour exposure with different copper concentrations. Serial dilutions of cells incubated without copper (control) or treated cultures were spotted in LB-agar plates. The last spot of each strip was loaded with 1/100000 dilution of original cultures. Data are representative of at least four independent experiments.

proton symport mechanism. Conversely, the excretion of the metal-phosphate complex via Pit generates a proton motive force in A. johnsonii [12].

Copper is an essential nutrient required for many biochemical functions, acting as a cofactor for several enzymes [13]. However, copper is also a toxic element able to catalyze free radicals formation, producing alteration of nucleic acids, lipids and proteins $[14,15]$. Thus, cells ensure their viability by a tight regulation of copper levels, involving several homeostatic mechanisms. E. coli is equipped with multiple systems to ensure copper handling under varying environmental conditions. For instance, the $\mathrm{Cu}^{+}$-translocating P-type ATPase CopA is responsible for removing excess $\mathrm{Cu}^{+}$from the cytoplasm. Multi-copper oxidase $\mathrm{CueO}$ and the multicomponent copper transport system CusCFBA appears to safeguard the periplasmic space from copper-induced toxicity [16-18]. In aerobic conditions, E. coli usually tolerate copper concentrations in the $\mu \mathrm{M}$ range, although minimal inhibitory concentrations for metals depend on the growth media and the methodology used [17-20].

Stationary phase cells are particularly vulnerable to oxidative damage since they lack the energy and materials needed to repair or replace the damaged molecules. In our laboratory, it has been demonstrated that E. coli stationary cells presented high viability, low oxidative damage and elevated resistance to exogenous $\mathrm{H}_{2} \mathrm{O}_{2}$ when Pi concentration in the medium was above $37 \mathrm{mM}$ [21]. These events were related to the maintenance of high polyP level in late stationary phase [22].

According to the model proposed previously by Keasling [7], we examined here the involvement of polyP metabolism and Pit system components in E. coli copper tolerance in stationary or exponential phase cells. Our approach included the use of mutants in PPK, PPX, PitA and PitB encoding genes and the modulation of polyP levels by varying media phosphate concentration.

\section{Results \\ $\mathrm{Cu}^{2+}$ tolerance of stationary phase cells grown in different phosphate concentration media}

The ability to tolerate $\mathrm{Cu}^{2+}$ of MC4100 wild-type (WT) cells, grown to stationary phase in media with different phosphate concentration, was evaluated by semiquantitative resistance assay (Figure 1A). Cells grown for $48 \mathrm{~h}$ in MT medium (sufficient Pi concentration) were sensitive to $0.25 \mathrm{mM} \mathrm{Cu}^{2+}$. Cells grown in $\mathrm{MT}+\mathrm{P}$ medium (high Pi concentration) tolerated metal concentrations as high as $4 \mathrm{mM}$. In agreement with previous results [22], Table 1 shows the maintenance of high polyP level in late stationary phase cells grown in MT $+\mathrm{P}$. Differences in tolerance due to media $\mathrm{Pi}$ concentration were also observed using $\mathrm{LB}$ and $\mathrm{LB}+\mathrm{P}$, defined as LB containing $40 \mathrm{mM}$ phosphate buffer $\mathrm{pH} 7$ [23], (data not shown).

As a first step to elucidate the differential copper tolerance in cells grown in MT or MT $+\mathrm{P}$ for $48 \mathrm{~h}$, assays using $p p k^{-} p p x^{-}$(unable to synthesize/degrade polyP $[24,25]$ ) and $p p x^{-}$(unable to degrade polyP) cells were performed in these conditions. Both mutants were highly sensitive to metal even in $\mathrm{MT}+\mathrm{P}$ (Figure $1 \mathrm{~B}$ and $\mathrm{C}$ ). Note that, polyP levels in $p p x^{-}$strain were always high, independently of the growth phase and the media used, while the $p p k p p x$ mutant exhibits greatly reduced synthesis of polyP, evidenced by low values of fluorescence emission (Table 1).

The implication of Pit system components in copper tolerance was also analyzed using $E$. coli strains lacking one or both transporter encoding genes (Figure 1D-F). pitA and pitB single mutants were unable to tolerate

Table 1 PolyP levels during growth in different Pi concentrations media

\begin{tabular}{|c|c|c|c|c|c|c|c|c|c|c|c|c|}
\hline & \multicolumn{12}{|c|}{ polyP $(\mathrm{AU})^{*}$} \\
\hline & \multicolumn{2}{|c|}{ MC4100 } & \multicolumn{2}{|c|}{$p p k^{-} p p x^{-}$} & \multicolumn{2}{|c|}{$p p x^{-}$} & \multicolumn{2}{|c|}{ pitA $^{-}$pitB } & \multicolumn{2}{|c|}{ pitA $^{-}$} & \multicolumn{2}{|c|}{ pitB } \\
\hline & MT & $\mathrm{MT}+\mathrm{P}$ & MT & $M T+P$ & MT & $\mathrm{MT}+\mathrm{P}$ & MT & $\mathrm{MT}+\mathrm{P}$ & MT & $M T+P$ & MT & $\mathrm{MT}+\mathrm{P}$ \\
\hline $6 \mathrm{~h}$ & $\begin{array}{l}123650 \pm \\
10540 a\end{array}$ & $\begin{array}{l}152951 \pm \\
8120 a\end{array}$ & $\begin{array}{l}45541 \pm \\
5563 a\end{array}$ & $\begin{array}{l}38254 \pm \\
4521 a\end{array}$ & $\begin{array}{l}220152 \pm \\
15120 a\end{array}$ & $\begin{array}{l}252651 \pm \\
11120 a\end{array}$ & $\begin{array}{l}80524 \pm \\
9452 a\end{array}$ & $\begin{array}{l}91523 \pm \\
8563 a\end{array}$ & $\begin{array}{l}82536 \pm \\
8652 a\end{array}$ & $\begin{array}{l}95623 \pm \\
9563 a\end{array}$ & $\begin{array}{l}81524 \pm \\
9452 a\end{array}$ & $\begin{array}{l}90523 \pm \\
5563 a\end{array}$ \\
\hline $24 \mathrm{~h}$ & $\begin{array}{l}54000 \pm \\
9500 b\end{array}$ & $\begin{array}{l}125420 \pm \\
10245 a\end{array}$ & $\begin{array}{l}42564 \pm \\
4521 a\end{array}$ & $\begin{array}{l}40251 \pm \\
6523 a\end{array}$ & $\begin{array}{l}200536 \pm \\
16245 a\end{array}$ & $\begin{array}{l}241536 \pm \\
12155 a\end{array}$ & $\begin{array}{l}32564 \pm \\
4152 b\end{array}$ & $\begin{array}{l}93056 \pm \\
6652 a\end{array}$ & $\begin{array}{l}24563 \pm \\
3254 b\end{array}$ & $\begin{array}{l}89654 \pm \\
10254 a\end{array}$ & $\begin{array}{l}28564 \pm \\
4152 b\end{array}$ & $\begin{array}{l}88056 \pm \\
8652 a\end{array}$ \\
\hline $48 \mathrm{~h}$ & $\begin{array}{l}44652 \pm \\
4556 b\end{array}$ & $\begin{array}{l}138456 \pm \\
8486 a\end{array}$ & $\begin{array}{l}38563 \pm \\
7521 a\end{array}$ & $\begin{array}{l}41251 \pm \\
5125 a\end{array}$ & $\begin{array}{l}208456 \pm \\
12486 a\end{array}$ & $\begin{array}{l}238456 \pm \\
10286 a\end{array}$ & $\begin{array}{l}22563 \pm \\
5634 b\end{array}$ & $\begin{array}{l}89862 \pm \\
4128 a\end{array}$ & $\begin{array}{l}32564 \pm \\
4635 b\end{array}$ & $\begin{array}{l}92365 \pm \\
8365 a\end{array}$ & $\begin{array}{l}20563 \pm \\
5634 b\end{array}$ & $\begin{array}{l}91862 \pm \\
4658 a\end{array}$ \\
\hline
\end{tabular}

*Fluorescence $550 \mathrm{~nm}$. For each strain, different letters indicate significant differences among conditions according to Tukey's test with a $p$-value of 0.05 . 
$0.5 \mathrm{mM} \mathrm{Cu}^{2+}$ in both media. This sensitivity was more pronounced in the pitApitB double mutant. It is worth noting that polyP levels in Pit system mutants depended on media Pi concentration, similarly to WT (Table 1).

Above results using different strains and culture media support the idea that stationary phase copper tolerance is mediated by a mechanism which involves both polyP metabolism and Pit system.

PolyP levels in cells exposed to $\mathrm{Cu}^{2+}$

Considering that the only presence or abundance of polyP during stationary phase is not sufficient to cope with copper toxicity in our conditions (see $p p x^{-}$sensitive phenotype), it might be that copper were responsible to induce degradation of polyP by PPX. In order to explore the occurrence of polymer degradation after metal addition, the effect of different $\mathrm{Cu}^{2+}$ concentrations on stationary phase polyP levels was evaluated in $\mathrm{MT}+\mathrm{P}$ cells (Figure 2A). A copper dependent decrease in polyP levels was observed in WT, pit $A^{-}$pitB, pit $^{-}$and pitB after one-hour exposure to metal. PolyP degradation induced by copper was dependent on PPX, since metal addition did not affect the polymer levels in $p p x$ mutant. PolyP degradation in WT cells took place immediately after copper addition (Figure 2B).

\section{Pi efflux in cells exposed to $\mathrm{Cu}^{2+}$}

In view of the copper dependent polyP degradation and discarding the chelating effect of the polymer, Pi liberated from the reaction could form complexes with the metal which would be taken out from the cell by Pit system, contributing to detoxify the intracellular environment. Thus, we aimed to test if metal also induces $\mathrm{Pi}$ extrusion in stationary phase cells. Time-dependent $\mathrm{Pi}$ release was measured in cells exposed to $0.25 \mathrm{mM} \mathrm{Cu}^{2+}$. WT cells released around $40 \mathrm{nmoles} \mathrm{Pi} \mathrm{mL}^{-1}$ at $30 \mathrm{~min}$ (Figure 3). For pitA and pitB single mutants, Pi exported at $30 \mathrm{~min}$ was $50 \%$ lower than that of WT cells. No Pi release was detected when pit $A^{-}$pitB $B^{-}$was used (Figure 3). It is worth noting that $\mathrm{Pi}$ was not detected in supernatants of either WT cells incubated without copper or $p p x^{-}$cells incubated with copper (data not shown). Viability of all tested strains was maintained after 30 min-exposure to $0.25 \mathrm{mM}$ copper in $\mathrm{T}$ buffer (data not shown). Taken together, Pi efflux would be associated to high polyP levels in stationary phase, its degradation in the presence of copper and to the functionality of the Pit system.

\section{Membrane polarization in cells exposed to $\mathrm{Cu}^{2+}$}

Since Pit was described as a metal-phosphate: $\mathrm{H}^{+}$symporter $[11,26]$, possible changes in cells membrane potentials after $\mathrm{Cu}^{2+}$ addition were studied. Figure 4 shows that copper produced a significant increase in membrane
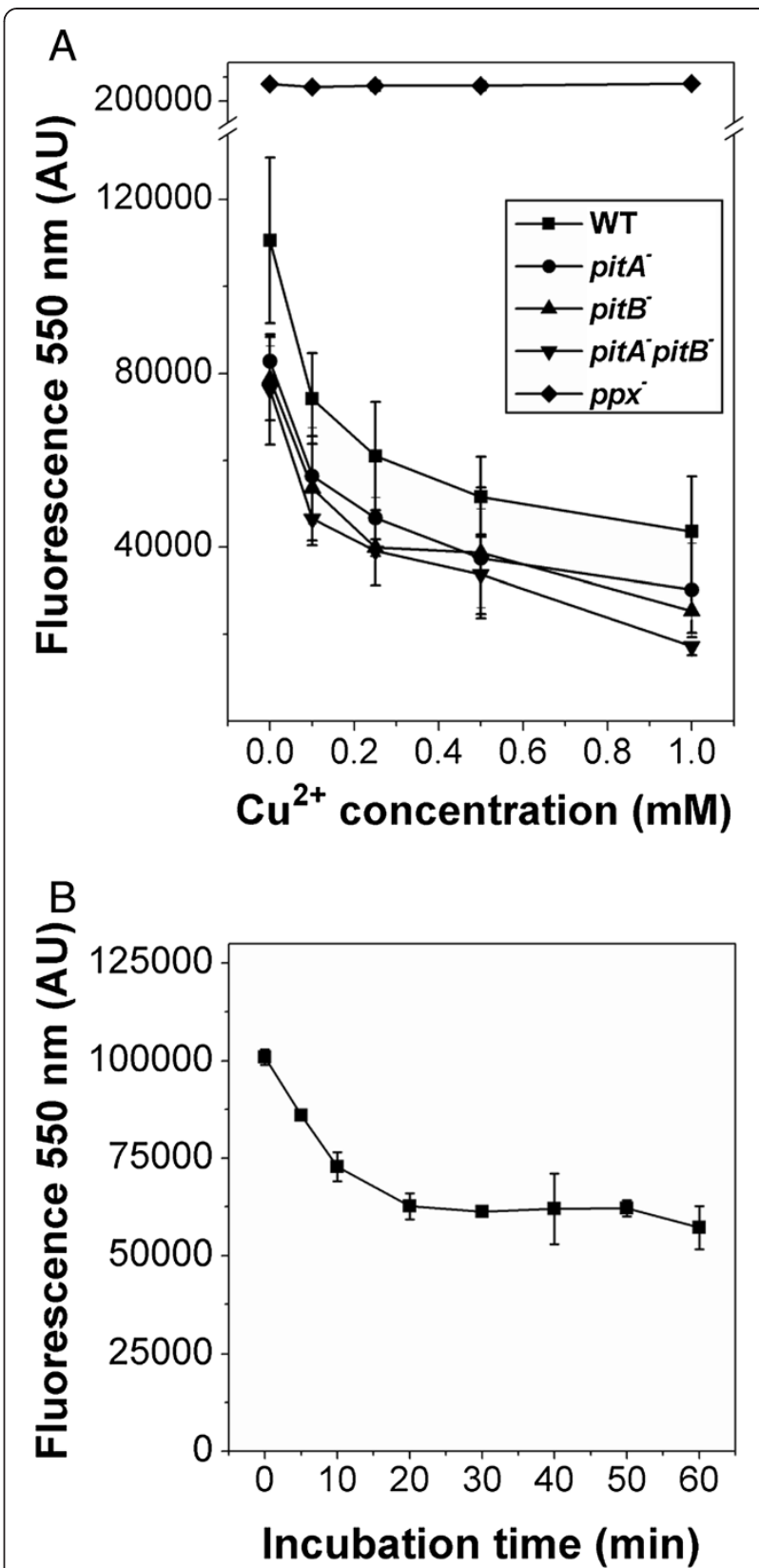

Figure 2 PolyP levels of stationary phase cells exposed to copper. (A) Cells of the indicated strains grown in MT $+\mathrm{P}$ for $48 \mathrm{~h}$ were exposed to increasing copper concentrations for $1 \mathrm{~h}$. After incubations, polyP was quantified as described in Methods using DAPI fluorescence. (B) Time-course of polyP degradation in $48 \mathrm{~h}$ MT + P WT cells incubated with $0.25 \mathrm{mM} \mathrm{Cu}^{2+}$. Data are expressed as average \pm SD of five independent experiments. DAPI emission was undetectable in cell free controls with or without copper addition.

polarization in MT $+\mathrm{P}$ WT cells in respect to values of MT WT cells or pitApitB and $p p x$ mutants in both media. When distillated water was added as a control, no changes in membrane polarization were observed (not shown). These data supported additional evidence indicating that metal-phosphate complexes can be 
Figure $3 \mathrm{Pi}$ efflux from stationary phase cells exposed to copper. $48 \mathrm{~h} \mathrm{MT}+\mathrm{P}$ cells of the indicated strains were resuspended in T buffer and exposed to $0.25 \mathrm{mM} \mathrm{Cu}^{2+}$ for the indicated times. Pi was quantified in supernatants as described in Methods. Data are expressed as average \pm SD of four independent experiments. Different letters indicate significant differences according to Tukey's test with a $p$-value of 0.05 .

removed from cells via Pit system after copperdependent polyP degradation.

\section{$\mathrm{Cu}^{2+}$ tolerance of exponential phase cells}

As shown above, polyP degradation and Pit system are involved in copper tolerance in stationary phase only in MT + P cells. Thus, we tested whether this detoxification mechanism is also feasible in exponential phase. During this phase, not only WT cells but also $p p x^{-}$and $p p k^{-} p p x$ - mutants were tolerant to $0.5 \mathrm{mM} \mathrm{Cu}{ }^{2+}$ even in MT (Figure 5A-C). PolyP degradation and Pi release were induced by copper exposure in WT cells grown in both media (Figures 6 and 7). These results are consistent with the presence of high intracellular polymer levels in WT cells at $6 \mathrm{~h}$ of growth, independently of media $\mathrm{Pi}$ concentration (Table 1). However, copper resistance of polyP metabolism lacking strains, indicates that another system is involved in $\mathrm{Cu}^{2+}$ tolerance during exponential phase. The involvement of CopA, a central component in E. coli copper detoxification during exponential phase [16], was evaluated in our experimental conditions using

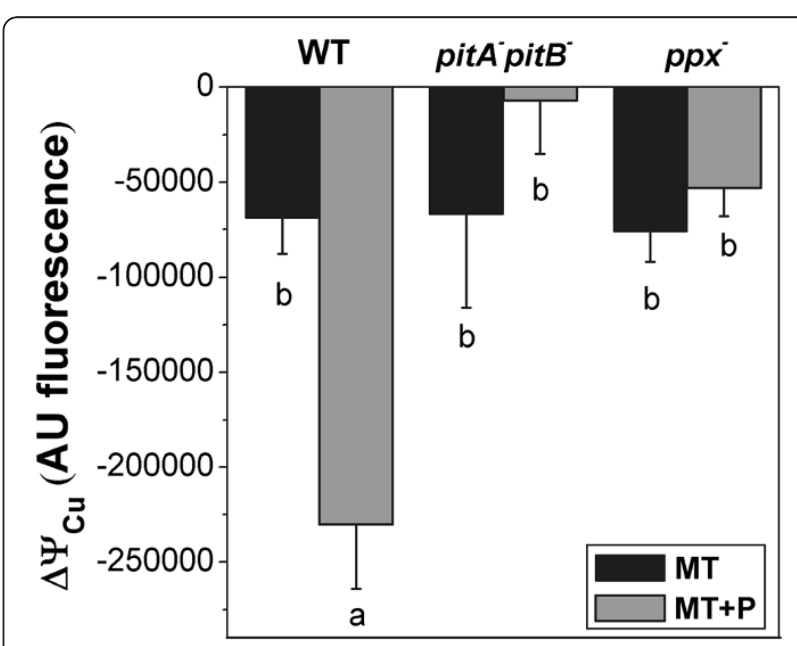

Figure 4 Membrane potential in stationary phase cells exposed to copper. $48 \mathrm{~h}$ MT or MT + P cells of the indicated strains were resuspended in T buffer and diluted in $5 \mathrm{mM}$ HEPES buffer $\mathrm{pH} 7.5$ to an $\mathrm{OD}_{560 \mathrm{~nm}}=0.1$. Fluorescence as Arbitrary Units (AU) was measured after addition of the specific dye DisC3[5]. After dye stabilization $0.1 \mathrm{mM} \mathrm{Cu}^{2+}$ was added. $\Delta \psi_{\mathrm{Cu}}$ was the difference between the fluorescence value after 5 min incubation with $\mathrm{Cu}^{2+}\left(\Delta \psi_{f}\right)$ and initial stabilization value $\left(\Delta \psi_{\mathrm{i}}\right)$. Data are expressed as average \pm SD of seven independent experiments. Different letters indicate significant differences according to Tukey's test with a $p$-value of 0.05 . 


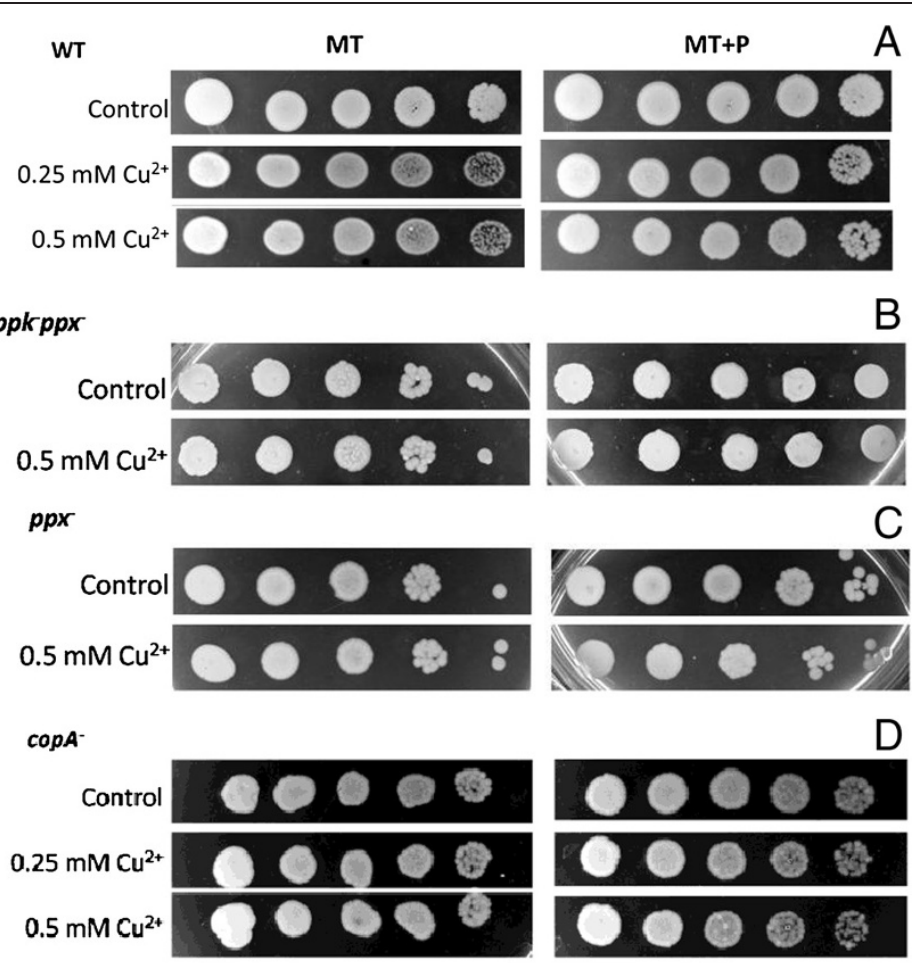

copA-ppkppx

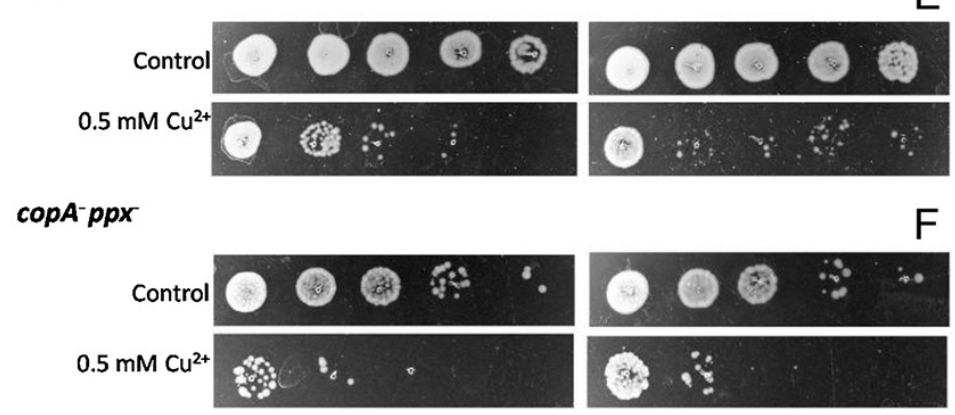

Figure 5 Copper tolerance in exponential phase cells. Copper tolerance of 6 h MT or MT + P growing cells of the indicated strains (panels AF) was determined after one-hour exposure with different copper concentrations. Serial dilutions of cells incubated without copper (control) or treated cultures were spotted in LB-agar plates. Data are representative of at least four independent experiments.

$\operatorname{cop} A^{-}, \operatorname{cop} A^{-} p p k^{-} p p x^{-}, \operatorname{cop} A^{-} p p x^{-}$strains. cop $A^{-}$cells were as resistant to copper as WT, while copAppkppx and $\operatorname{copAppx}$ mutants were highly sensitive to copper exposure (Figures 5D-F). As in WT, polyP degradation and Pi efflux occurred upon copper exposure in the cop $A^{-}$background (Figures 6 and 7). Together, in order to tolerate copper in exponential phase, polyP-Pit system could be active to safeguard CopA absence or vice versa.

\section{Discussion}

Cellular functions can be disrupted when $\mathrm{Cu}^{2+}$ concentration exceeds acceptable levels [27]. In order to survive the adverse environment, several mechanisms of resistance are switched on in bacteria [28]. In the present study, we demonstrated that polyP levels and Pit system are involved in $E$. coli copper tolerance.

In stationary phase, the significant metal resistance of WT cells grown in high phosphate medium could be attributed to the high polyP level in this condition [22], which could also account for enhancement in stationaryphase fitness [21]. The copper sensitivity of $p p k^{-} p p x^{-}$is in agreement with previous work showing that this double mutant is deficient in stationary phase functions and lacks stress resistance $[22,24,25]$. On the other hand, considering $p p x$ single mutant sensitive phenotype, not only polyP presence but also its degradation is relevant for $\mathrm{Cu}^{2+}$ resistance in our conditions, discarding the role of polymer merely as a metal chelator. The chelating effect constitutes one line of thought linking the metal tolerance and the 


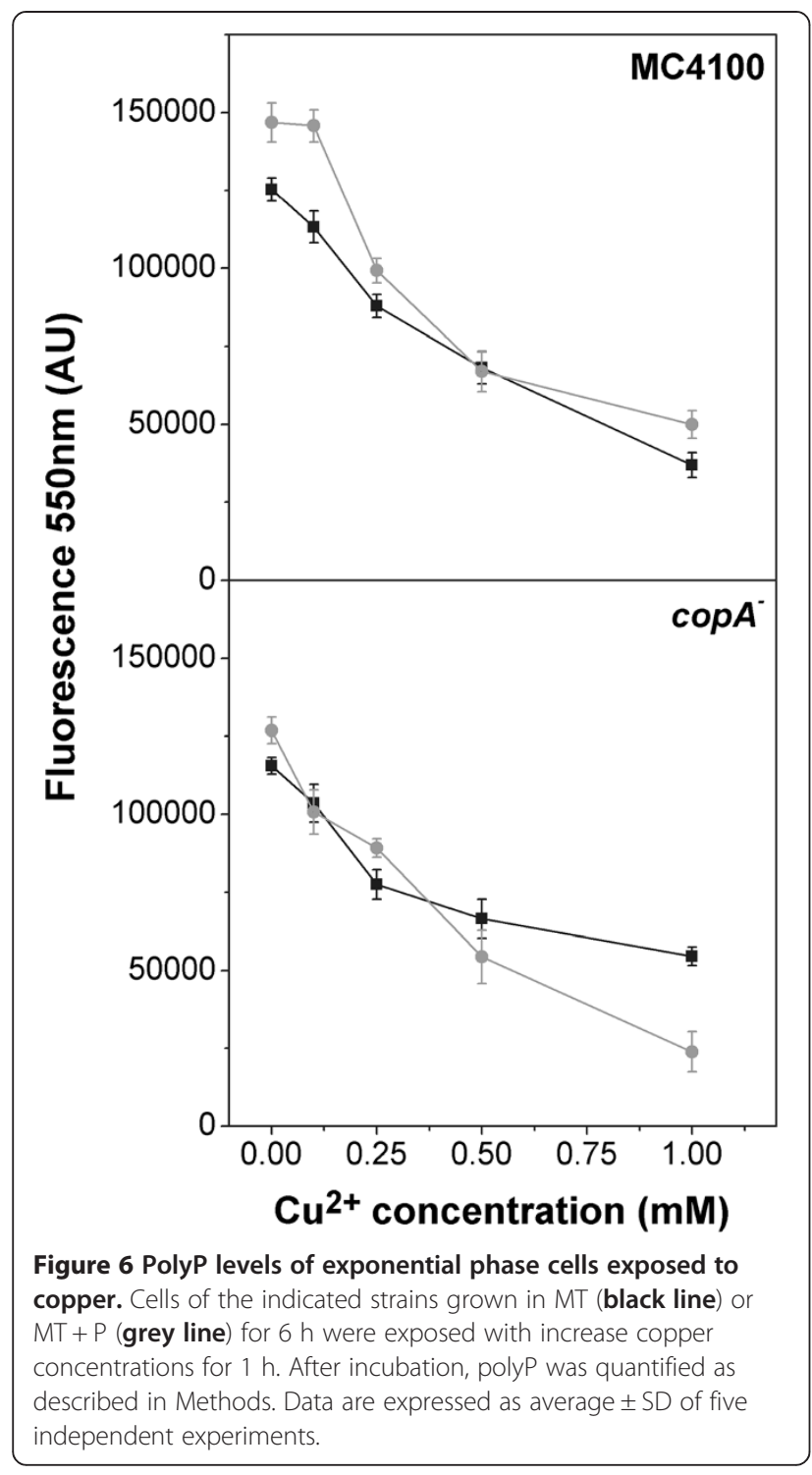

polymer; however, abundance of polyP in exopolyphosphatase deficient strain may be damaging for the cell. Note that polymer molecules with high capacity to bind metal ions represent a source of potentially toxic species in equilibrium with the intracellular medium. Degradation of preformed polyP and Pi-copper complex formation that can be exported from the cells represent another alternative way to detoxify metals. In fact, our results provided lines of evidence that copper-induced polyP degradation through PPX in few minutes of exposure. In agreement, Acidithiobacillus ferrooxidans and Sulfolobus metallicus cells underwent to an increase of exopolyphosphatase activity with a concomitant decrease in polyP levels with increasing copper concentrations [8,9]. In addition, viability assays with Pit system mutants indicate, for the first time, the direct involvement of PitA and PitB in E. coli copper tolerance, as it was previously suggested for other metals

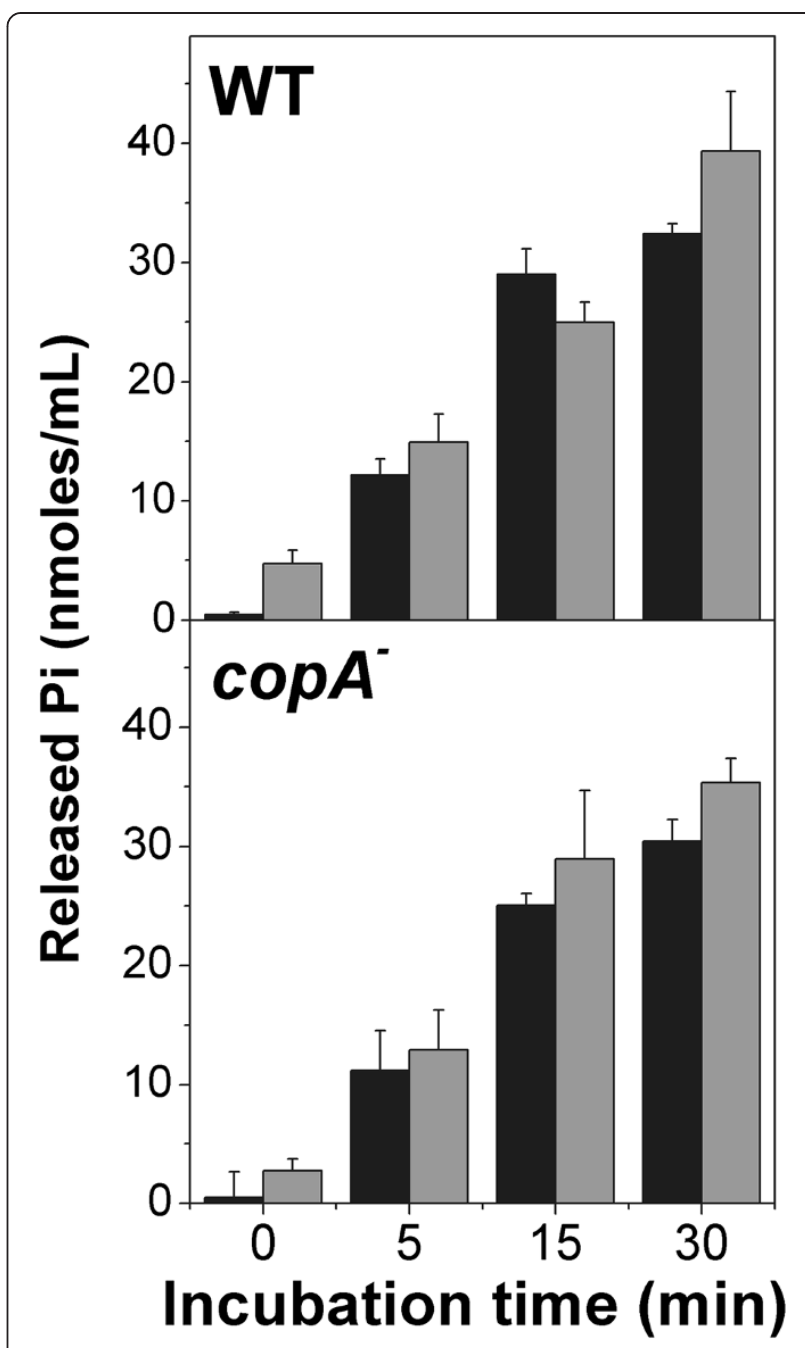

Figure $7 \mathrm{Pi}$ efflux from exponential phase cells exposed to copper. $6 \mathrm{~h}$ MT (black bars) or MT + P (grey bars) cells of the indicated strains were resuspended in T buffer and exposed to $0.25 \mathrm{mM} \mathrm{Cu}^{2+}$ during different times. Pi was quantified in supernatants as described in Methods. Data are expressed as average \pm SD of three independent experiments.

[7] and copper [8,9]. Levels of pitA gene expression were invariant due to copper addition in each of our experimental conditions (data not shown). Expression was high in exponential phase either in MT and MT + P cells and moderate in stationary MT $+\mathrm{P}$ cells, coincidentally with copper tolerance conditions. In sufficient Pi medium MT, expression decay during stationary phase, where viability was impaired and polyP was minimal.

We consider that copper tolerance is a consequence of changes in polyP levels exerted by the metal. Even when copper efflux or formation of intracellular copper-phosphate complexes were not determined in this work, high Pi release and elevated membrane polarization in MT + P WT stationary phase cells, evidence that high polyP levels and its metal-induced degradation would lead to 
$\mathrm{Cu}^{2+}$-phosphate complexes formation and their subsequent efflux. Low changes in membrane polarization generated after copper addition in other strains and conditions may be due to differential diffusion of ions that induces complex movement of buffer and other ions.

According to present data and our previous results [21-23,29], the salt composition of the culture media should be carefully considered in the experimental design, especially when stationary-phase events are studied. Note that commonly used minimal media, as M63 [30] and M9 [31], contain $\mathrm{Pi}$ concentrations higher than $40 \mathrm{mM}$. Our strategy using differential Pi concentration media, allowed us to find the first copper detoxification mechanism acting in $E$. coli stationary phase, which only involves polyP-Pit system and is functional in high phosphate media. It should be noted that no copper induction of $\operatorname{cop} A$ gene expression was observed in stationary phase in all the tested media (data not shown).

Our data show that polyP-Pit system is involved in copper tolerance also in exponential phase. Actually, CopA absence could be counteracted by a functional polyP-Pit system and, conversely, CopA would be responsible for metal tolerance in a polyP or Pit deficient background. Even we could not discard the participation of other copper detoxification mechanisms already described to be functional during this phase $[17,19,28]$, CopA or polyP-Pit systems seem to be necessary to safeguard cells against copper toxicity, according to sensitive phenotypes of $\operatorname{cop} A^{-} p p k^{-} p p x^{-}$and $\operatorname{cop} A^{-} p p x^{-}$strains. As it was previously described for E. coli [22], Pseudomonas fluorescens [32] Corynebacterium glutamicum [33], Bacillus cereus [34] and a wide range of microorganisms [35], high polyP levels were reached in the early exponential growth phase. Thus, polyP-Pit system would be a very important aspect to consider as an additional copper tolerance mechanism in bacterial exponential phase.

\section{Conclusion}

In conclusion, this work shed light on the previously proposed polyP-dependent mechanism for metal resistance in microorganisms. PolyP degradation and functionality of Pit, postulated as a metal-phosphate transporter system, mediates copper tolerance in $E$. coli both in exponential and stationary cells. Data represent the first experimental evidence of the involvement of Pit system components in this detoxification mechanism. Our study may also help to understand the importance of the environmental salt composition to regulate the microbial physiological state.

\section{Ethics Statement}

The present research does not involve human subjects, human material, human data, or animals.

\section{Methods}

\section{Strains and growth conditions}

Bacterial strains are shown in Table 2. Mutations and copA-lacZ transcriptional fusion were transduced by P1 vir lysates into MC4100 strain. Cells were grown aerobically at $37^{\circ} \mathrm{C}$ with linear shaking in the saline minimal media, MT (2 mM phosphate) [36] and MT + P (defined as MT containing $40 \mathrm{mM}$ phosphate buffer $\mathrm{pH}$ 7) [23]. Media were supplemented with $0.5 \%$ glycerol and $0.1 \%$ tryptone. Growth was monitored by measuring $\mathrm{OD}_{560}$ $\mathrm{nm}$. When required, the following antibiotics were used:

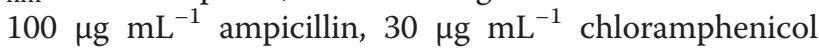
and $50 \mu \mathrm{g} \mathrm{mL}^{-1}$ kanamycin.

\section{$\mathrm{Cu}^{2+}$ tolerance determination}

Cells grown in MT and MT $+\mathrm{P}$ during 6, 24 or $48 \mathrm{~h}$ were incubated with shaking at $37^{\circ} \mathrm{C}$ for $1 \mathrm{~h}$ with different $\mathrm{CuSO}_{4}$ concentrations in the same culture media. Identical aliquots of cells incubated without copper were used as controls. Then, metal tolerance was evaluated by qualitative viability assays, spotting $1 / 10$ serial dilutions on LB-agar [21]. Plates were incubated for $24 \mathrm{~h}$ at $37^{\circ} \mathrm{C}$.

\section{PolyP level measurement}

Intracellular polyP was measured in cell suspensions by a fluorescence approach using 4',6-diamidino-2-phenylindole

Table 2 E. coli strains and plasmids used in this work

\begin{tabular}{|c|c|c|}
\hline $\begin{array}{l}\text { Strains and } \\
\text { plasmids }\end{array}$ & Relevant genotype or description & $\begin{array}{l}\text { Construction or } \\
\text { reference }\end{array}$ \\
\hline MC4100 & $\begin{array}{l}\text { araD, lac, rpsL, flbB, deoC, ptsF, rbsR, } \\
\text { relA1 }\end{array}$ & {$[37]$} \\
\hline LSB022 & MC4100 (ppkppx::Km) & {$[22]$} \\
\hline $\begin{array}{l}\mathrm{LSB022/} \\
\mathrm{pBC} 29\end{array}$ & LSB022/pBC29((ppkppx::Km /ppk+, Ap) & [29] \\
\hline RKP2935 & RKP4353 [Ф(pitA-lacZ)] pitA:: Cm & [38] \\
\hline AN3901 & JC7623 pitB::Cm & [39] \\
\hline AN4080 & pitA1 pitB:: $\mathrm{Cm}$ & [39] \\
\hline LSB026 & MC4100 pitA:: Cm & $\begin{array}{l}\text { (P1(RKP2935) } \\
\text { xMC4100) }\end{array}$ \\
\hline MGP001 & MC4100 pitB:: Cm & $\begin{array}{l}\text { (P1(AN3901) } \\
\text { XMC4100) }\end{array}$ \\
\hline JW0473-3 & $\begin{array}{l}\text { F-, araD-araB, lacZ, copA::km } \lambda^{-}, r p h-1, \\
\text { rhaD-rhaB, hsdR }\end{array}$ & CGSC \\
\hline MGP002 & MC4100 copA::Km & $\begin{array}{l}\text { (P1(JW0473-3) } \\
\text { XMC4100) }\end{array}$ \\
\hline MGP003 & MGP002 copA::FRT & This study \\
\hline MGP004 & MGP003 ppkppx::Km, copA $A^{-}$ & $\begin{array}{l}(\mathrm{P} 1(\mathrm{LSB022}) \\
\mathrm{xMGP003)}\end{array}$ \\
\hline MGP005 & $\begin{array}{l}\text { MGP004 /pBC29 ((ppkppx::Km, } \\
\left.\text { CopA }^{-} / p p k^{+}, A p\right)\end{array}$ & This study \\
\hline $\mathrm{pBC} 29$ & $\left(p p k^{+}, A p\right)$ & {$[24]$} \\
\hline pCP20 & Ap, Cm, cl857 IPR flp pSC101 oriTs & {$[40]$} \\
\hline
\end{tabular}


(DAPI) [41]. Briefly, cells were washed and resuspended in T buffer (100 mM Tris-HCl, pH 8). $17 \mu \mathrm{M}$ DAPI (Sigma) was added to cuvettes containing cell suspensions $\left(\mathrm{OD}_{560}\right.$ $\mathrm{nm}=0.02$ ) in $\mathrm{T}$ buffer, with $0.075 \%$ SDS and chloroform for cell permeabilization [29]. After $5 \mathrm{~min}$ at $37^{\circ} \mathrm{C}$ with agitation, the DAPI fluorescence spectra (excitation, $415 \mathrm{~nm}$; emission, 445-650 nm) were recorded using an ISS PCI spectrofluorometer (ISS Inc., Champaign, IL). Fluorescence of the DAPI-polyP complex at $550 \mathrm{~nm}$ was used as a measurement of intracellular polyP, since emissions from free DAPI and DAPI-DNA are minimal at this wavelength [41]

\section{Membrane electrical potential measurement}

Changes in the transmembrane electrical potential $(\Delta \Psi)$ were measured utilizing the potential sensitive fluorescent probe 3,3'-dipropylthiadicarbocyanine (DisC3 [5]) [42]. Briefly, cells were harvested by centrifugation, washed twice with $100 \mathrm{mM}$ T buffer and resuspended in $5 \mathrm{mM}$ HEPES buffer pH 7.5 to an OD $560 \mathrm{~nm}=0.1$. Cell suspensions were incubated with shaking plus $0.4 \mu \mathrm{M}$ DisC3 [5] and 0.4\% glucose. Fluorescence measurements were carried out at $37^{\circ} \mathrm{C}$, adjusting the wavelengths of excitation and emission to 622 and $675 \mathrm{~nm}$, respectively. When the dye uptake was maximal, as indicated by a decrease to a steady fluorescence value, $\left(\Delta \Psi_{\mathrm{i}}\right), 0.1 \mathrm{mM} \mathrm{Cu}^{2+}$ was added and fluorescence was followed for $5 \mathrm{~min}$, achieving $\Delta \Psi_{\mathrm{f}}$. The difference between $\Delta \Psi_{\mathrm{f}}$ and $\Delta \Psi_{\mathrm{i}}$ was defined as $\Delta \Psi_{\mathrm{Cu}}$. Measurements were repeated at least seven times under each condition. Distillated water was added instead of $\mathrm{Cu}^{2+}$ solutions in negative control.

\section{Pi efflux determination}

Cells were harvested and thoroughly washed by four steps of centrifugation and resuspension with $\mathrm{T}$ buffer to eliminate Pi present in the media. Then, cells were resuspended to the original volume in the same buffer (OD

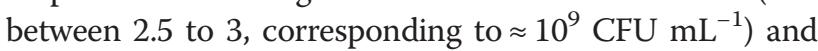
incubated with agitation in the presence of $0.25 \mathrm{mM} \mathrm{Cu}^{2+}$ at $37^{\circ} \mathrm{C}$ for the indicated times. Phosphate was determinate in supernatants using ammonium molybdate and ascorbic acid as described by Chifflet et al. [43]. T buffer incubated with copper for $60 \mathrm{~min}$ and cells without metal were used as negative controls.

\section{Gene expression}

Gene expression was evaluated by $\beta$-galactosidase activity and expressed in Miller Units (MU) [44].

\section{Statistical analysis}

Data were subjected to analysis of variance (ANOVA) followed by Tukey's test with Statitix 9.0 Analytical Software 2008 for Windows (USA). Differences at $p$-value of 0.05 were considered significant.

\section{Competing interests}

The authors declare that they have no competing interests.

\section{Authors' contributions}

MGP carried out determinations of $\mathrm{Cu}^{2+}$ tolerance, polyP level, membrane electrical potential, Pi efflux, and gene expression. LASB initiated experiments in $\mathrm{Cu}^{2+}$ tolerance and polyP level measurements. MGP and LRM performed statistical analysis. MGP, MRR, and VAR prepared the manuscript and participated in the analysis of data. All authors designed the study and revised the manuscript for intellectual content. All authors read and approved the final manuscript.

\section{Acknowledgment}

We gratefully acknowledge Dr R. K. Poole for providing the strain RKP2935 and Dr S. Howitt for providing the strains AN3901 and AN4080. This research was supported by Argentinean grants of the Consejo Nacional de Investigaciones Científicas y Técnicas (CONICET), the Agencia Nacional de Promoción Científica y Técnica (ANPCyT) and the Consejo de Investigaciones de la Universidad Nacional de Tucumán (CIUNT). M.G.P. thanks CONICET for doctoral fellowship.

\section{Author details}

${ }^{1}$ Instituto Superior de Investigaciones Biológicas, INSIBIO (CONICET-UNT) and Instituto de Química Biológica "Dr Bernabé Bloj", Facultad de Bioquímica, Química y Farmacia (UNT), Chacabuco 461 CP T4000ILI, Tucumán, Argentina. ${ }^{2}$ Present address: Department of Biochemistry, University of Illinois, Urbana IL61801, USA.

Received: 26 November 2013 Accepted: 14 March 2014 Published: 19 March 2014

\section{References}

1. Akiyama M, Crooke E, Kornberg A: The polyphosphate kinase gene of Escherichia coli. Isolation and sequence of the ppk gene and membrane location of the protein. J Biol Chem 1992, 267(31):22556-22561.

2. Akiyama M, Crooke E, Kornberg A: An exopolyphosphatase of Escherichia coli. The enzyme and its $p p x$ gene in a polyphosphate operon. J Biol Chem 1993, 268(1):633-639.

3. Kornberg A, Rao NN, Ault-Riche D: Inorganic polyphosphate: a molecule of many functions. Annu Rev Biochem 1999, 68:89-125.

4. Rachlin JW, Jensen TE, Baxter M, Jani V: Utilization of morphometric analysis in evaluating response of Plectonema boryanum (Cyanophyceae) to exposure to eight heavy metals. Arch Environ Contam Toxicol 1982, 11(3):323-333.

5. Keyhani S, Lopez JL, Clark DS, Keasling JD: Effect of polyphosphate on cadmium tolerance in the cyanobacterium Anacystis niduluns R2. Microbios 1996, 88:105-114.

6. Aiking $H$, Stijnman A, van Garderen C, van Heerikhuizen H, van 't Riet J: Inorganic phosphate accumulation and cadmium detoxification in Klebsiella aerogenes NCTC 418 growing in continuous culture. Appl Environ Microbiol 1984, 47(2):374-377.

7. Keasling JD: Regulation of intracellular toxic metals and other cations by hydrolysis of polyphosphate. Ann N Y Acad Sci 1997, 829:242-249.

8. Alvarez S, Jerez CA: Copper ions stimulate polyphosphate degradation and phosphate efflux in Acidithiobacillus ferrooxidans. Appl Environ Microbiol 2004, 70(9):5177-5182.

9. Remonsellez F, Orell A, Jerez CA: Copper tolerance of the thermoacidophilic archaeon Sulfolobus metallicus: possible role of polyphosphate metabolism. Microbiology 2006, 152(Pt 1):59-66.

10. Willsky GR, Malamy MH: Characterization of two genetically separable inorganic phosphate transport systems in Escherichia coli. J Bacteriol 1980, 144(1):356-365.

11. van Veen HW, Abee T, Kortstee GJJ, Konings WN, Zehnder AJB: Phosphate inorganic transport (Pit) system in Escherichia coli and Acinetobacter johnsonii. In Phosphate in Microorganisms: cellular and molecular biology. Washington, DC: American Society for Microbiology; 1994.

12. van Veen HW, Abee T, Kortstee GJJ, Pereira H, Konings WN, Zehnder AJB: Generation of a proton motive force by the excretion of metalphosphate in the polyphosphate-accumulating Acinetobacter johnsonii strain 210A. J Biol Chem 1994, 269(47):29509-29514.

13. Linder MC: Biochemistry of copper. Plenum, New York: Springer; 1991. 
14. Gutteridge JM, Halliwell B: Free radicals and antioxidants in the year 2000 . A historical look to the future. Ann N Y Acad Sci 2000, 899:136-147.

15. Linder MC: Copper and genomic stability in mammals. Mutat Res 2001, 475(1-2):141-152.

16. Grass G, Rensing C: Genes involved in copper homeostasis in Escherichia coli. J Bacteriol 2001, 183(6):2145-2147.

17. Outten FW, Huffman DL, Hale JA, O'Halloran TV: The independent cue and cus systems confer copper tolerance during aerobic and anaerobic growth in Escherichia coli. J Biol Chem 2001, 276(33):30670-30677.

18. Franke S, Grass G, Rensing C, Nies DH: Molecular analysis of the coppertransporting efflux system CusCFBA of Escherichia coli. J Bacterio/ 2003, 185(13):3804-3812.

19. Yamamoto K, Ishihama A: Transcriptional response of Escherichia coli to external copper. Mol Microbiol 2005, 56(1):215-227.

20. Macomber L, Imlay JA: The iron-sulfur clusters of dehydratases are primary intracellular targets of copper toxicity. Proc Natl Acad Sci U S A 2009, 106(20):8344-8349.

21. Schurig-Briccio LA, Farias RN, Rodriguez-Montelongo L, Rintoul MR, Rapisarda VA: Protection against oxidative stress in Escherichia coli stationary phase by a phosphate concentration-dependent genes expression. Arch Biochem Biophys 2009, 483(1):106-110.

22. Schurig-Briccio LA, Farias RN, Rintoul MR, Rapisarda VA: Phosphateenhanced stationary-phase fitness of Escherichia coli is related to inorganic polyphosphate level. J Bacterio/ 2009, 191(13):4478-4481.

23. Schurig-Briccio LA, Rintoul MR, Volentini SI, Farias RN, Baldoma L, Badia J, Rodriguez-Montelongo L, Rapisarda VA: A critical phosphate concentration in the stationary phase maintains ndh gene expression and aerobic respiratory chain activity in Escherichia coli. FEMS Microbiol Lett 2008, 284(1):76-83.

24. Crooke E, Akiyama M, Rao NN, Kornberg A: Genetically altered levels of inorganic polyphosphate in Escherichia coli. J Biol Chem 1994, 269 (9):6290-6295.

25. Rao NN, Kornberg A: Inorganic polyphosphate supports resistance and survival of stationary-phase Escherichia coli. J Bacteriol 1996, 178(5):1394-1400

26. Rosenberg H, Gerdes RG, Harold FM: Energy coupling to the transport of inorganic phosphate in Escherichia coli K12. Biochem J 1979, 178(1):133-137.

27. Bruins MR, Kapil S, Oehme FW: Microbial resistance to metals in the environment. Ecotoxicol Environ Saf 2000, 45(3):198-207.

28. Rensing C, Grass G: Escherichia coli mechanisms of copper homeostasis in a changing environment. FEMS Microbiol Rev 2003, 27(2-3):197-213.

29. Grillo-Puertas M, Villegas JM, Rintoul MR, Rapisarda VA: Polyphosphate degradation in stationary phase triggers biofilm formation via LuxS quorum sensing system in Escherichia coli. PLoS One 2012, 7(11):e50368.

30. Silhavy TJ, Berman ML, Enquist LW: Experiments with Gene Fusions. In. 1st edition. Cold Spring Harbor, New York: Cold Spring Harbor Laboratory; 1984.

31. Sambrook J, Russell DW: Molecular Cloning: A Laboratory Manual. Cold Spring Harbor, New York; 2001.

32. Silby MW, Nicoll JS, Levy SB: Regulation of polyphosphate kinase production by antisense RNA in Pseudomonas fluorescens $p$ f0-1. Appl Environ Microbio/ 2012, 78(12):4533-4537.

33. Klauth P, Pallerla SR, Vidaurre D, Ralfs C, Wendisch VF, Schoberth SM: Determination of soluble and granular inorganic polyphosphate in 349 Corynebacterium glutamicum. Appl Microbiol Biotechnol 2006, 72:1099-1106.

34. Shi X, Rao NN, Kornberg A: Inorganic polyphosphate in Bacillus cereus: motility, biofilm formation, and sporulation. Proc Natl Acad Sci U S A 2004, 101(49):17061-17065.

35. Kulakova AN, Hobbs D, Smithen M, Pavlov E, Gilbert JA, Quinn JP, McGrath JW: Direct quantification of inorganic polyphosphate in microbial cells using 4'-6-diamidino-2-phenylindole (DAPI). Environ Sci Technol 2011 45(18):7799-7803.

36. Simon EH, Tessman I: Thymidine-Requiring Mutants of Phage T4. Proc Natl Acad Sci U S A 1963, 50:526-532.

37. Casadaban MJ, Cohen SN: Lactose genes fused to exogenous promoters in one step using a Mu-lac bacteriophage: in vivo probe for transcriptional control sequences. Proc Natl Acad Sci U S A 1979, 76(9):4530-4533.

38. Jackson RJ, Binet MR, Lee $\sqcup$, Ma R, Graham Al, McLeod CW, Poole RK: Expression of the PitA phosphate/metal transporter of Escherichia coli is responsive to zinc and inorganic phosphate levels. FEMS Microbiol Lett 2008, 289(2):219-224.

39. Harris RM, Webb DC, Howitt SM, Cox GB: Characterization of PitA and PitB from Escherichia coli. J Bacteriol 2001, 183(17):5008-5014.
40. Cherepanov PP, Wackernagel W: Gene disruption in Escherichia coli: TcR and $\mathrm{KmR}$ cassettes with the option of Flp-catalyzed excision of the antibiotic-resistance determinant. Gene 1995, 158(1):9-14

41. Aschar-Sobbi R, Abramov AY, Diao C, Kargacin ME, Kargacin GJ, French RJ, Pavlov E: High sensitivity, quantitative measurements of polyphosphate using a new DAPI-based approach. J Fluoresc 2008, 18(5):859-866.

42. Sims PJ, Waggoner AS, Wang CH, Hoffman JF: Studies on the mechanism by which cyanine dyes measure membrane potential in red blood cells and phosphatidylcholine vesicles. Biochemistry 1974, 13(16):3315-3330.

43. Chifflet S, Torriglia A, Chiesa R, Tolosa S: A method for the determination of inorganic phosphate in the presence of labile organic phosphate and high concentrations of protein: application to lens ATPases. Anal Biochem 1988, 168(1):1-4

44. Miller JF: Procedures for working with lac. In A short course in bacterial genetics: a laboratory manuals and handbook for Escherichia coli and related bacteria. New York: Cold Spring Harbor Laboratory Press; 1992.

doi:10.1186/1471-2180-14-72

Cite this article as: Grillo-Puertas et al: Copper tolerance mediated by polyphosphate degradation and low-affinity inorganic phosphate transport system in Escherichia coli. BMC Microbiology 2014 14:72.

\section{Submit your next manuscript to BioMed Central and take full advantage of:}

- Convenient online submission

- Thorough peer review

- No space constraints or color figure charges

- Immediate publication on acceptance

- Inclusion in PubMed, CAS, Scopus and Google Scholar

- Research which is freely available for redistribution

Submit your manuscript at www.biomedcentral.com/submit
C Biomed Central 